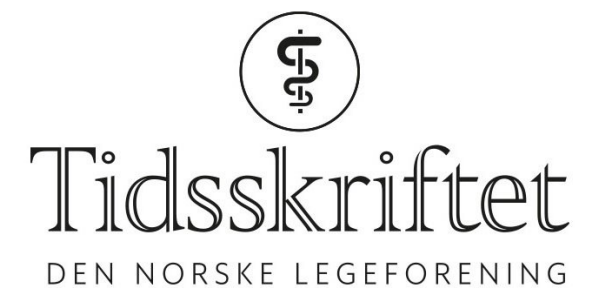

DEN NORSKE LEGEFORENING

\title{
Organisk uro på geriatrisk avdeling
}

LEGELIVET

MARTE SYVERTSEN

E-post: marsyv@vestreviken.no

Marte Syvertsen (f. 1982) er lege i spesialisering og doktorgradsstipendiat ved Nevrologisk avdeling i Drammen.

I et villnis av forvirrende og vanskelig hjerneforskning er det i alle fall godt at vi har presise begreper, som for eksempel organisk hjernesykdom.

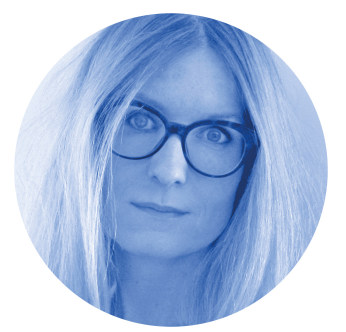

Jeg var medisinstudent og satt fastvakt på geriatrisk avdeling. Der var det høyt under taket og store dobbeltdører i treverk, sånne dører som aldri passer helt sammen når du prøver å lukke dem. Fru Hansen og fru Nilsen hadde vekket hverandre hele natta. Den ene var hofteoperert. Jeg husker ikke hva som var i veien med den andre, men hun reiste seg ustanselig fra senga og klaget samtidig over smerter. Jeg forsøkte å forklare at det var bedre å ikke stå på bena hvis det gjorde så vondt. Endelig la hun seg ned. Da ropte fru Hansen, og så sto fru Nilsen opp igjen. Det var mitt første møte med delirium, og faktisk var det akkurat da jeg bestemte meg for ikke å bli psykiater.

Året før hadde jeg praksisutplassering i psykiatri på et statlig sykehus i Milano. Det var også et gammelt bygg. Flere pasienter måtte dele rom, og det var gitter foran vinduene.

«Men jeg har det jo strålende!» ropte en av damene, mens hun reiste seg fra senga og slo ut med armene. «Problemet er,» sa legen som gikk visitt, «at De har det litt for strålende, frue.»

Etterpå var jeg med på en samtale hvor det ble brukt Rorschach-tavler. Pasienten var en nett, eldre dame med krøllete hår. Hun så carne umana i alle bildene. Menneskekjøtt, altså.

På slutten av psykatripraksisen tok en av legene meg til side. Hun ville bruke litt tid på å fortelle at ingen andre fagfelt kunne måle seg med hennes. Tenk, at å snakke sammen faktisk er en direkte del av behandlingen. Forløpet av en sykdom kan modifiseres med ord. Hun hadde rett $\mathrm{i}$ at det er helt fabelaktig. Men hun formidlet også en annen veldig viktig sak, nemlig det brennende engasjementet for eget fagfelt. Vis meg en kardiolog som ikke mener at hjertet er det mest sentrale vi har i kroppen, og jeg skal fortelle deg at han eller hun kanskje trenger omskolering. Vis meg en anestesilege som ikke tenker på at hver dag reddes det liv, eller en kirurg som aldri har sagt at det er jo på operasjonsstuen at ting blir gjort. Det 
er dette som driver oss fremover, som gjør at vi går den ekstra meteren, ser på YouTubeklipp med blod og innvoller og har fagtidsskrifter på nattbordet. Applaus.

Når det er sagt, så ville verken armer, ben, hjerte eller lunger fungert uten hjernen. Det er mange organer som skal rime på noe om dagen, men at hjernen er stjernen, kunne vel neppe vært formulert bedre. Samtidig er hjernen den delen av kroppen hvor mest er ukjent, og det er vel fordi den hele tiden må prøve å forstå seg selv. Det som er bra, er at vi i alle fall har presise begreper, som for eksempel organisk hjernesykdom. Jeg er bare litt usikker på hvilke typer sykdommer som ikke er organiske. Mener vi sykdom som ikke kommer fra et organ? Hvor kommer det fra da i så fall? Oppstår det utenfor kroppen eller på et slags hemmelig sted i oss som ikke har substans? Synes vi det er slitsomt med problemstillinger som ikke kan forklares ved hjelp av molekyler eller røntgenbilder? Jeg syntes i hvert fall at fru Hansen og fru Nilsen var helt umulige, selv om de strengt tatt kanskje hadde en organisk form for uro.

Sant å si så er det vel bare å bite i gresset, eventuelt det sure eplet, og innrømme at det er en del ting menneskeheten ennå ikke har forstått. For 150 år siden trodde folk at de fleste sykdommer kunne kureres ved å tappe ut blod. Det er nok ikke sånn at vi er allvitende nå heller. Heldigvis. Et relativt ferskt eksempel på det, er anti-NMDA-reseptorencefalitt. Denne pasientgruppen, med dramatiske atferdsendringer, vrangforestillinger og hallusinasjoner, seilte under radaren inntil 2007. Da så noen et mønster, begynte å undre seg og fant til slutt ut at det var autoantistoffer mot NMDA-reseptorer som satte disse pasientenes liv på hodet (1).

Å være lei seg, sier du, det er ikke en organisk sykdom. Nei, det er kanskje ikke alltid en sykdom. Men hvis en dement pasient begynner å gråte fordi det er feil farge på tabletten, da kaller vi det for emosjonell labilitet, og $d a$ er det plutselig et symptom. Følelsesuttrykk kommer også fra hjernen. Vi forstår hva som skjer ved et epileptisk anfall, men hva gjør at vi plutselig handler og tenker annerledes? Hvorfor er det sånn et en rekke mennesker med samme type epilepsi også ser ut til å ha visse personlighetstrekk til felles? Og hva er det som går galt ved autisme? Er det interessen for andre som går tapt? Hvilken hjernefunksjon er det?

René Descartes sa nok mange lure ting for fire hundre år siden, men kanskje er tiden inne for å fastslå at dualismen hans har gått ut på dato. Res extensa og res cogitans er to sider av samme sak. Det skarpe skillet mellom kropp og sjel, psyke og soma forvirrer oss fremdeles. I stedet for å snakke om kroppen, det somatiske, som noe eget og sjelen eller psyken som noe annet, burde vi kanskje gå over til å kalle alt sammen for mennesket. To ting er i hvert fall sikkert. Det ene er at hjernen sitter øverst, og det andre er at den består av mer enn motorisk cortex og basalganglier.

LITTERATUR:

1. Engen K, Agartz I. Anti-NMDA-reseptorencefalitt. Tidsskr Nor Legeforen 2016; 136: 1006 - 9. [PubMed][CrossRef]

Publisert: 8. januar 2018. Tidsskr Nor Legeforen. DOI:10.4045/tidsskr.17.099o

(C) Tidsskrift for Den norske legeforening 2020. Lastet ned fra tidsskriftet.no 